\title{
Space Law: Intergovernmental Financial Relations and Regulation of Confidentiality
}

\author{
Andriana Bryhinets \\ Ph.D., Ministry of Infrastructure of Ukraine (Kyiv, Ukraine) \\ E-mail: andriana_bryhinets@ukr.net

\section{Oleksii Drozd} \\ Doctor of Law, Associate Professor, National Academy of Internal Affairs \\ (Kyiv, Ukraine) \\ E-mail: info@asljournal.org
}

\begin{abstract}
The discovery of space for research and use has had a significant impact on society. In its activities, the person has ceased to be limited to planetary scale, and began to project its future in the cosmos. There was a need for the development and improvement of legislation regulating human activity in space. In particular, the regulation of confidentiality in financial relations between private enterprises operating in space, as well as in intergovernmental financial relations. In the paper, the author examines the experience of confidentiality regulation in intergovernmental financial relations of the leading countries of the world. The results will serve as the basis for improving the relevant provisions of space law.
\end{abstract}

Keywords: space law; commercial secrets; regulation of confidentiality; legal support; intergovernmental financial relations.

\section{Космічне право: міжурядові фінансові відносини та регулювання конфіденційності}

\section{Бригінець, Андріана Василівна}

Кандидат юридичних наук, Управління запобігання корупції, внутрішніх розслідувань та державного фінансового моніторингу Міністерства інфраструктури України

(Київ, Україна)

\section{Дрозд, Олексій Юрійович}

Доктор юридичних наук, доцент, начальник відділу докторантури та ад’юнктури

Національної академії внутрішніх справ (Київ, Україна)

(C) Bryhinets, Andriana, 2018

(C) Drozd, Oleksii, 2018 
Space Law: Intergovernmental Financial Relations and Regulation of Confidentiality

by Andriana Bryhinets and Oleksii Drozd

Відкриття космосу для дослідження і використання суттєво вплинуло на суспільство. У свойй діяльності людина перестала обмежуватися планетарними масштабами, а почала проектувати своє майбутнє в масштабах космосу. Виникла необхідність розвитку $і$ вдосконалення законодавства, щуо регулює діяльність людини у космосі. Зокрема, регулювання конфідениійності в фінансових відносинах між приватними підприємствами, щуо працюють у космосі, а також в міжурядових фінансових відносинах. В статті автор розглядає досвід регулювання конфіденційності в міжурядових фінансових відносинах провідних держав світу. Отримані результати слугуватимуть підгрунтям для вдосконалення відповідних положень космічного права.

Ключові слова: космічне право; комериійна таємниця; регулювання конфідениійності; правове забезпечення; міжурядові фінансові відносини.

Received: February 1, 2018; accepted: February 27, 2018

Advanced Space Law, Volume 1, 2018: 14-23.

https://doi.org/10.29202/asl/2018/1/2

\section{Постановка проблеми}

На сторінках авторитетних наукових журналів в останні кілька років обговорюється можливість створення космічної нації. Наприклад у статті Романа Олексенко та Лідії Фьодорової «Ното Еconomicus як основа Держави “Асгардія” у космосі», розглядаються можливості освітніх технологій в Державі “Асгардія” [Oleksenko \& Fedorova, 2017]. Автори виходять із факту фактичного створення першої в світі космічної держави “Асгардія.” Правовий пакет “Асгардія” включає створення нової правової платформи для дослідження навколоземного і далекого космосу. Замість міжнародного космічного права i геополітики правове регулювання в “Асгардії” грунтується на положеннях «Універсального космічного права» і «астрополітіки» [Ashurbeyli, 2016]. I хоча на перший погляд «створення космічної нації», «космічної цивілізації», «універсального космічного права», здаються утопією і сюрреалізмом, кількість публікацій та наукових досліджень в цій галузі змушують звернути на себе увагу.

По суті дійсно, відкриття космосу для дослідження і використання суттєво вплинуло на суспільство. Дистанційне зондування Землі супутниками покращило метеорологію, землекористування та моніторинг навколишнього середовища. Супутникове телебачення та новітні телекомунікаційні технології забезпечили миттєве розповсюдження інформації, та посилили іiі вплив на суспільство. Можливість 3 космосу поглянути на Землю, і на процеси, які відбуваються на ній, змінили свідомість людини. Перші космічні туристи, політ на Місяць, плани Ілона Маска здійснювати регулярні рейси на Марс і створити там населену станцію тощо, відкрили можливість розселення людини в космосі. Розробляються навігаційні карти для космічних подорожей, які враховують точне розташування космічних тіл і їх гравітаційних полів в просторі [Литвинчук, 2016]. У своїй діяльності людина перестала обмежуватися планетарними масштабами, а почала проектувати своє майбутнє в масштабах космосу. Книга «Космічне право» Френсіс Лайал і Пола Б. Ларсена вносить пропозиції щодо розвитку і вдосконалення законодавства, що регулює діяльність людини у космосі. Зокрема, регулювання конфіденційності в фінансових відносинах між приватними підприємствами, що працюють у космосі [Lyall \& Larsen, 2007]. 
В статті ми розглянемо досвід регулювання конфіденційності в міжурядових фінансових відносинах провідних держав світу. Отримані результати, на наш погляд, слугуватимуть підгрунтям для вдосконалення відповідних положень космічного права.

Метою статті є визначення сутності проблем регулювання конфіденційності в міжурядових фінансових відносинах.

\section{Виклад основного матеріалу}

Розробка та прийняття відповідних нормативно-правових актів у сфері регулювання конфіденційності в міжурядових фінансових відносинах у розвинених державах світу, визначається як важлива і відповідальна діяльність. 3 історичних фактів відомо, що основоположними правовими актами у інформаційній сфері були закони про охорону державної таємниці, тобто законодавчі документи у галузі захисту інформації. У ФРН для належного захисту вітчизняних секретів були спеціально визначені кримінально-правові наслідки за протиправні діяння, пов’язані з розголошенням, передачею або втратою важливих державних документів та секретів, шпигунство, а також інших дії, які наносили шкоду державі. Німецьке Уложення 1871 року передбачало позбавлення волі за розголошення відомостей, які необхідно було зберігати у таємниці від інших держав [Князєв и др., 2005: 45].

Крім розробки й прийняття законодавчих актів у інформаційній сфері, до заходів охорони конфіденційності в міжурядових фінансових відносинах належать:

1. Видання директив, положень, інструкцій, методичних рекомендацій, які безпосередньо регламентують режим використання інформації на підприємствах, установах, організаціях;

2. Проведення спеціальної перевірки осіб на компетентність у роботі з документами, матеріалами й виробами, що містять інформацію конфіденційного характеру;

3. Впровадження посиленої фізичної та технічної охорони об'єктів, на яких зберігаються матеріали, що потребують захисту;

4. Періодичне проведення різнопланових профілактичних заходів тощо.

У кримінальному законодавстві держав континентальної системи права існують свої відповідні норми, що охороняють конфіденційність в міжурядових фінансових відносинах. Наприклад, Кримінальний кодекс Королівства Іспанії (далі - Іспанія) містить детальну регламентацію кримінально-правової охорони комерційної таємниці. У діючому правовому акті зазначається, що той, хто з метою розкрити комерційну таємницю заволодіє яким-небудь способом відомостями, письмовими або електронними документами, інформаційними пристроями або іншими об'єктами, які відносяться до комерційної таємниці, карається відповідно до норм чинного законодавства [Уголовный кодекс, 1998]. Передбачене законодавством покарання значно збільшується якщо розкрита таємниця буде поширюватися, видана або передана третім особам. Ряд норм Кримінального кодексу Іспанії передбачає відповідальність за наслідки, що настали через розголошення конфіденційної інформації економічного характеру.

У Кримінального кодексі Французької Республіки (далі - Франція) правова регламентація охорони конфіденційності у фінансово-правових відносинах регламентована досить детально. Наприклад, розділ «Про зазіхання на таємницю», містить перелік злочинів можливих у відповідній сфері [Уголовный кодекс, 2010]. 
Кримінальне законодавство центральних держав Європи містить свої характерні особливості регламентації кримінально-правової охорони конфіденційності в міжурядових фінансових відносинах. Наприклад, Кримінальний кодекс ФРН основу класифікації таємниці зосереджує на злочинах проти публічних інтересів та злочинах проти приватних інтересів [Кузнецова \& Вельцель, 1980: 43-44]. Законодавчо визначається відповідальність за незаконне розголошення таємниць довірену особі, яка стала їй відомою під час здійснення власної діяльності. Встановлюється кримінальна відповідальність за використання відомостей, що становлять комерційну таємницю, яку особа зобов'язана була зберігати. Винятковий обов'язок щодо стосовно збереження комерційної таємниці покладено на посадових осіб фіскальних органів. Наприклад, відповідальності підлягає особа, яка безпідставно розголошує або використовує виробничу чи комерційну таємницю, яка їй не належить, але стала відома як посадовій особі під час такої діяльності. Питання стосовно боротьби з розкраданням секретів виробництва у сфері промисловості й торгівлі сформульовані досить детально у діючому законодавстві. До них відносяться: «Федеральний закон про охорону даних», «Закон про боротьбу з несумлінною конкуренцією», «Постанова про боротьбу з підкупом не посадових осіб» тощо. Для вдосконалення існуючого захисту конфіденційності у фінансово-правових відносинах у ФРН реалізовуються такі напрямки, а саме: деталізація та оновлення законодавства у сфері захисту державної таємниці; посилення органів безпеки та надання їм більших повноважень; створення організацій «самодопомоги» у промисловості й розгортання їхньої діяльності. Вважаємо, що у ФРН, як і у цілому в державах-членах Європейського Союзу (далі - СС) недостатність засобів покарання, передбачених чинним законодавством не сприяють підвищенню ефективності боротьби з промисловим шпигунством. Іншою причиною німецькі вчені вбачають у протидії, яку промислові кола роблять спробам посилення заходів щодо охорони секретів виробництва, оскільки за нормами «Закону про несумлінну конкуренцію» постраждалі фірми часто уникають звертатися в судові органи з ряду причин, у тому числі побоюючись підриву своєї комерційної репутації.

Огляд сучасного законодавства розвинених держав як загального, так і континентального права дає можливість вести мову про наявну спільність кримінально-правової охорони конфіденційності в міжурядових фінансових відносинах [Кибальник и др., 2001]. Крім того, у багатьох провідних державах використовується позитивна практика стосовно збереження конфіденційності працівниками підприємств за відповідною угодою. Особа не допускається до такої інформації, або ж взагалі не приймається на роботу без укладання такої угоди. Відповідно, на службовців, так само як на працівників приватного сектора, досить часто покладається відповідне зобов'язання не розголошувати інформації з обмеженим доступом. Зобов'язання зберігати інформацію можуть поширюватись на відомості, що стосуються політики, виробничої, наукової та комерційної діяльності, а також на особисті дані працівників. Також службовці можуть бути зобов'язані зберігати інформацію особистого характеру їхніх стосунків з громадянами. Зауважимо, що конфіденційність у окремих випадках вступає у конфлікт із тим, що відноситься до інтересів суспільства. Наприклад, у Великобританії інтерес суспільства визнається важливішим від питань збереження конфіденційності. У розвинених європейських державах при прийомі на роботу, пов'язану з використання інформації 3 обмеженим доступом досить часто використовується спеціальний прилад - поліграфа. Також його використовують при проведенні розслідувань, пов'язаних з витоком інформації обмеженої у доступі. 
У США досить багато осіб без попереднього попередження проходять перевірку на поліграфі, що є умовою продовження з ними контракту. Дана умова обумовлюється в вищезазначеній угоді [Климчук, 2006: 158-164]. Сучасні детектори є доволі складними приладами, які одночасно охоплюють кілька фізіологічних процесів людини. Але відношення до поліграфу, особливо у державах-членах ЄС є неоднозначним. Наприклад, у ФРН поліграф не може використовуватися при прийомі на роботу. Вважається, що дана перевірка багато у чому залежить від підготовленості оператора, який скеровує даний пристрій.

Необхідно звернути увагу на те, що Великобританія законодавчо не закріплювала захист конфіденційності у цілому, а також у фінансово-правових відносинах зокрема. I тільки 1981 року був прийнятий Закон «Про порушення конфіденційності». Вказаний нормативний акт і до сьогодні регулює усі питання, пов'язані з конфіденційністю, встановлює відповідальність за порушення конфіденційності, а також засоби судового захисту, застосовувані при таких процедурах. Дещо пізніше з введенням у дію Закону «Про свободу інформації» було запроваджено певну процедуру розголошення інформації 3 обмеженим доступом, якою володіють органи державної влади або особи, які надають послуги громадянам. При розголошенні такої інформації аналізується можливість заподіяної шкоди певним інтересам. Проте, положення даного нормативно-правового акту чітко не визначили випадки, у яких органи влади повинні так діяти. Обмеження доступу до інформації залежить від даних, що містяться у документі: інформація, пов'язана 3 питаннями національної безпеки; інформація, з якою працюють судові органи; записи судових органів; інформація, стосовно державної політики; інша конфіденційна інформація.

Особливу увагу уряд приділяє захисту секретних відомостей державного апарату. Розроблені спеціальні рекомендації стосовно правил поводження та дотримання таємниці під час виконання службових обов'язків. Відповідно до вказаних рекомендацій члени кабінету міністрів зобов'язані підтримувати імідж і єдність англійського уряду та зберігати у таємниці усе, що стосується їх діяльності. При призначенні на посаду необхідною умовою $є$ проходження інструктажу з питань забезпечення державної безпеки. Інструктаж проводять працівники служби безпеки та контррозвідки. Призначений на посаду кожний новий член уряду підписує декларацію, яка засвідчує його ознайомлення 3 основними постулатами Закону «Про державну таємницю». Керуючись положеннями закону про державну таємницю, а також закону про конфіденційність пріоритетним завданням уряду стає вжиття активних заходів щодо попередження та запобігання витоку секретних відомостей через засоби масової інформації. Відповідно до положень вказаних нормативних актів, уряд має право вимагати через суд першої інстанції заборонити публікацію матеріалів, які містять секретні відомості. Разом з тим, автору можуть заборонити публікування матеріалів і за кордоном. У той же час, суд має право зобов'язати автора забрати рукопис з будь-якого іншого видавництва. У разі, якщо автор бажає, щоб заборона була знята йому необхідно подати на розгляд зміст публікації, а також перелік використаних джерел. 1995 року розроблено нову процедуру перевірки державних службовців, які мають доступ до секретної інформації. Пришвидшили реалізацію даного заходу часті випадки підкупу посадових осіб, у тому числі і спецслужбами іноземних держав. Перевірки банківських рахунків та кредитних платежів здійснюються стосовно службовців, які мають тривалий та неконтрольований доступ до секретних документів. Про всі випадки виявлення внесків підозрілого походження відразу інфор- 
мується служба безпеки. Особи, які мають доступ до цілком таємних матеріалів, перевіряються найбільш детально. У першу чергу це стосується працівників спецслужб, котрі працюють під прикриттям за кордоном або виконують обов'язки офіцерів зв'язку при штаб-квартирах іноземних спецслужб.

Дослідження основних положень законодавства дозволяє говорити про те, що у його основі закладена ідея систематизації інформації з обмеженим доступом. Таким чином, прослідковується відмова від поділу інформації з обмеженим доступом на державну таємницю та конфіденційну інформацію. 3 цієї позиції, основну роль відіграють різновиди обмеження доступу до інформації, які встановлюються законодавством. Виходячи 3 вищезазначеного, «конфіденційність» слід розглядати як ознаку інформації з обмеженим доступом, а також як ключова характеристика ії правового режиму. На жаль, у законі не наведено повний перелік інформації з обмеженим доступом, а лише зазначені найбільш типові їі різновиди. Вказана спроба систематизації інформації з обмеженим доступом отримала неоднозначні відгуки наукової спільноти. В основному причинами цього являється різне тлумачення та розуміння значення термінів «конфіденційна інформація», «конфіденційність», «таємність».

Значна частина науковців, вважає рівнозначними між собою вищезгадані поняття. Окрему увагу приділяють конфіденційній інформації, вказуючи, що це основний термін для позначення всієї інформації з обмеженим доступом [Ефремов, 2004]. У той же час, як справедливо вказує Людмила Терещенко, поняття «конфіденційна інформація» має свої певні особливості. Наслідком цього не вся інформація з обмеженим доступом може розглядатися як така [Терещенко, 2008: с. 72]. Термін «конфіденційний» можна дослівно перекласти як «довірчий», по відношенню безпосередньо до інформації, у випадках передачі іï власником іншим суб'єктам, тобто забезпечити ії конфіденційність. Необхідність останнього викликана наявністю у власника, яке може опинитися під загрозою у результаті поширення інформації або передачі без згоди останнього третім особам. У даному випадку «конфіденційність» як вимога стосується виключно особи, яка відповідно до норм закону, а також за бажанням власника отримала доступ до інформації чи інших відомостей. Що стосується останнього, то власник, як правило, має право розпоряджатися та контролювати обіг інформації, що становить таємницю. Наприклад, усі існуючі різновиди таємниць фактично віднести до переліку «конфіденційної інформації» неможливо. У переважній більшості, власник, тобто суб'єкт таємниці, здійснює ії охорону самостійно та не передає інформацію іншим особам. У випадках передачі відомостей іншим особам вони набувають статусу держателя інформації, проте, режим таємниці або інформації при цьому змінюється. При передачі відомостей державним органам така інформація вже охороняється у режимі службової таємниці. Таким чином, конфіденційною інформація стає у разі передачі іiі особі, вимушеної на підставі закону забезпечувати її конфіденційність, у першу чергу в інтересах власника. Як бачимо, термін «конфіденційність» може бути застосовано виключно до держателів інформації, у той час як власник здійснює безпосередній захист інформації, як правило, добровільно, у своїх власних інтересах, так само як і відмовляється від неї. Зазначимо, що термін «конфіденційність» широко використовується у відносинах, що виникають між роботодавцем до працівником, тобто у трудових відносинах. У даному випадку, найманих працівників тимчасово допускають до такого виду інформації для виконання ними власних посадових обов'язків.

Зауважимо, що конфіденційність інформації виступає досить часто основою роботи з аудиторськими організаціями. Виходячи $з$ того, що аудиторські організації отримують 
доступ до повної та достовірної інформації про осіб, то саме на них спрямовується підвищена увага з боку правоохоронних органів та інших установ, що виявляють інтерес до цієї інформації. Важливою проблемою забезпечення конфіденційності інформації аудиторських організацій є питання про державне регулювання даної діяльності. Закон «Про аудиторську діяльність» зобов'язує аудиторів дотримуватись аудиторської таємниці, та передбачає іiі надання державним органам лише у окремих виняткових випадках. Саме тому, аудиторські організації повинні забезпечити максимальне виконання таких заходів забезпечення конфіденційності інформації, як, наприклад, розробка і впровадження політики інформаційної безпеки, яка являє собою документ, що містить перелік організаційних заходів забезпечення безпеки інформації та їі цілісності. Враховуючи думку експертів ключовим аспектом розробки політики інформаційної безпеки виступає аналіз ризиків інформаційної сфери, який полягає аналізі ймовірних загроз, а також перелік заходів, необхідних для запобігання реалізації загроз щодо ресурсів організації [Чернова, 2009]. Зазвичай застосовуються кілька підходів до аналізу ризиків, зокрема: базовий, що включає у себе перевірку стандартного захисту від поширених загроз і виконання вимог сертифіката безпеки, та цілісний, що передбачає більш прискіпливу оцінку ресурсів підприємства. Більш доцільним вважаємо використання цілісного підходу до аналізу ризиків власної інформаційної системи.

Аудиторські організації повинні керуватися стандартами аудиторської діяльності, які базуються на принципах проведення аудиторської діяльності, а саме: конфіденційності, незалежності, професійної етики. Будь-яка аудиторська організація зобов'язана виробляти власні стандарти, з метою практичної реалізації зазначених принципів. Працівники аудиторських організацій повинні знати внутрішні стандарти та виконувати їх. Як бачимо, будь-яка діяльність аудиторських організацій безпосередньо пов'язана 3 конфіденційністю у фінансово-правових відносинах, а саме: фінансовою інформацією, що є предметом власності інших юридичних осіб. Саме у цьому полягає специфіка аудиторської діяльності, адже аудиторські організації зобов'язані не лише захищати дану інформацію, але і забезпечувати іiї конфіденційність. Особливістю вказаної діяльності є ї те, що терміни дії аудиторської таємниці не встановлені законодавством, тобто передбачено обов'язок зберігати у таємниці конфіденційну інформацію про операції клієнтів, отриману при наданні професійних послуг, без обмеження термінів та незалежно від продовження або припинення безпосередніх відносин з ним. Виходячи з норм чинного законодавства не вірне використання інформаційних ресурсів, що перебувають у володінні аудиторських організацій, може спричинити за собою серйозні наслідки. Максимальним із них визнається позбавлення волі на строк до трьох років з позбавленням права обіймати певні посади чи займатися певною діяльністю. Саме тому аудиторські організації повинні дотримуватися принципу конфіденційності та впроваджувати елементи політики інформаційної безпеки, яка здатна не тільки забезпечити конфіденційність інформації, що захищається, але і її доступність і цілісність. Нажаль, через відсутність загальних вимог щодо забезпечення безпеки конфіденційної інформації відповідні суб'єкти повинні розробляти та застосовувати комплекс заходів на власний розсуд.

Як бачимо, досліджувана проблема забезпечення і дотримання конфіденційності інформації дослідниками розглядається досить по-різному. Доволі поширеним у науці $\epsilon$ уявлення про те, що при отриманні конфіденційної інформації відповідний режим таємниці перетворюється з одного режиму в інший. Наприклад, відомості про діяльність юридичних осіб являються предметом комерційної таємниці, але вказана діяльність 3 
банківськими рахунками захищається режимом банківської таємниці. При наданні таких відомостей до фіскальних органів виникають відносини з приводу податкової таємниці, наприклад режим податкової таємниці або службової таємниці. Тобто, банківська, комерційна, професійна таємниці, персональні дані після подання їх до контролюючих органів не припиняють своє функціонування, так як до органів виконавчої влади передається не режим, а сама інформація. Конфіденційна інформація стає не тільки об'єктом обміну між особами та органами державної влади; у середині однієї організації можуть функціонувати відомості, що становлять комерційну таємницю, персональні дані, різновиди професійної таємниці, щодо яких власник повинен забезпечити конфіденційність.

Вищезгадані приклади свідчать, що для забезпечення конфіденційності однієї і тієї ж інформації доводиться встановлювати різні режими, які можуть призвести до виникнення конфліктів інтересів суб'єктів таємниць, тобто для виключення конфліктів при здійсненні інформаційного обміну доцільно закріпити у нормативних актах поняття «режим конфіденційності інформації», який дозволив би встановити єдині правила i вимоги до забезпечення безпеки інформації в органах державної влади, так і юридичних осіб та грунтувався б на основі оцінки ризиків суб'єкта таємниці в міжурядових фінансових відносинах. Використовуючи оцінку ризиків в міжурядових фінансових відносинах здійснюється виявлення загроз активів, оцінка уразливості відповідних активів та ймовірності виникнення загроз. Також важливим визнається використання законодавчих вимог для забезпечення узгодженості, цілеспрямованості, планомірності діяльності по забезпеченню інформаційної безпеки; оцінка можливих наслідків; визначення адекватності заходів захисту з урахуванням принципу оптимальності витрат на захист конфіденційності в міжурядових фінансових відносинах.

\section{Висновки}

Варто зазначити, що дослідження позитивного зарубіжного досвіду розвинених держав, з метою поширення базових та основоположних підвалин даної сфери у космічне право є, безумовно, актуальним як з наукового, так і з практичного погляду. Слід вказати, що режим конфіденційності в міжурядових фінансових відносинах визначається як предмет правового регулювання, який являє собою особливий правовий порядок, встановлений державою за допомогою правових норм і забезпечений нею шляхом роботи з інформацією конфіденційного характеру, що включає в себе: збір, накопичення, зберігання, уточнення, систематизацію, використання, поширення, знищення. У зв’язку 3 цим розвинені держави при захисті власних інформаційної системи використовують відповідні механізми для іiї охорони. Ефективність запровадження таких механізмів вимагає врахування передового досвіду у інформаційній сфері стосовно належного регулювання конфіденційності в міжурядових фінансових відносинах.

\section{Література}

Ефремов, Алексей. Понятие и виды конфиденциальной информации. Право и экономика. 4, 2004: 46-47.

Князєв, С. О., Ботвінкін, О. В., Колєснік, О. А. Генезис системи охорони державной таємниці на території України: Аналітичний огляд. Київ: Видавництво НА СБ України, 2005. 
Кибальник, А. Г., Масленников, А. В., Соломоненко, И. Г. Уголовная ответственность за незаконные получение и разглашение сведений, составляющих коммерческую или банковскую тайну. Ставрополь, 2001.

Климчук, С. Загальна характеристика законодавства про інформаційну безпеку ЄС, США та Канади. Київ: Юстініан, 2006.

Кузнецова, Н. Ф., Вельцель, Л. Уголовное право ФРГ. Москва: Изд-во Московского унта, 1980.

Литвинчук, Николай. Парадоксы навигационной карты (модели) звёздного неба для дальних космических путешествий. Philosophy and Cosmology 2015 (Vol. 14): 8390.

Терещенко, Людмила. Правовой режим информаџчии. Москва, 2008.

Уголовныий кодекс Испании. Под редакцией Н.Ф. Кузнецовой и Ф.М. Решетникова. Москва: ЗЕРЦАЛО, 1998.

Уголовный кодекс Франиии. СПб.: Юрид. Центр Пресс, 2010.

Чернова, Е. В., Попова, Е. В., Попова, И. В., Зленко И. В. Обеспечение безопасности системы информационно-аналитической поддержки научных исследований. Программные продукты и системы. 4, 2009.

Ashurbeyli, Igor. Concept “Asgardia - the Space Nation”. October 12, 2016. https://asgardia. space/en/page/concept

Lyall, Francis and Paul B. Larsen. Space Law. Routledge, 2007.

Oleksenko, Roman and Lidiia Fedorova. Homo Economicus as the Basis of "Asgardia" Nation State in Space: Perspective of Educational Technologies. Future Human Image. Volume 7, 2017: 113-119.

\section{[D] References}

Efremov, Aleksei. Poniatye y vydы konfydentsyalnoi ynformatsyy. Pravo y эkonomyka. 4, 2004: 46-47.

Kniaziev, S. O., Botvinkin, O. V., Koliesnik, O. A. Henezys systemy okhorony derzhavnoi taiemnytsi na terytorii Ukrainy: Analitychnyi ohliad. Kyiv: Vydavnytstvo NA SB Ukrainy, 2005.

Kybalnyk, A. H., Maslennykov, A. V., Solomonenko, Y. H. Uholovnaia otvetstvennost za nezakonnble poluchenye y razghlashenye svedenyi, sostavliaiushchykh kommercheskuiu yly bankovskuiu tainu. Stavropol, 2001.

Klymchuk, S. Zahalna kharakterystyka zakonodavstva pro informatsiinu bezpeku YeS, SShA ta Kanady. Kyiv: Yustinian, 2006.

Kuznetsova, N. F., Veltsel, L. Uholovnoe pravo FRH. Moskva: Yzd-vo Moskovskoho un-ta, 1980.

Lytvynchuk, Nykolai. Paradoksы navyhatsyonnoi kartы (modely) zvëzdnoho neba dlia dalnykh kosmycheskykh puteshestvyi. Philosophy and Cosmology 2015 (Vol. 14): 8390 .

Tereshchenko, Liudmyla. Pravovoi rezhym ynformatsyy. Moskva, 2008.

Uholovnbil kodeks Yspanyy. Pod redaktsyei N.F. Kuznetsovoi y F.M. Reshetnykova. Moskva: ZERTsALO, 1998.

Uholovnai kodeks Frantsyy. SPb.: Yuryd. Tsentr Press, 2010. 
Chernova, E. V., Popova, E. V., Popova, Y. V., Zlenko Y. V. Obespechenye bezopasnosty systemы ynformatsyonno-analytycheskoi podderzhky nauchnыkh yssledovanyi. Prohrammnble produktbl y systembl. 4, 2009.

Ashurbeyli, Igor. Concept “Asgardia - the Space Nation”. October 12, 2016. https://asgardia. space/en/page/concept

Lyall, Francis and Paul B. Larsen. Space Law. Routledge, 2007.

Oleksenko, Roman and Lidiia Fedorova. Homo Economicus as the Basis of "Asgardia" Nation State in Space: Perspective of Educational Technologies. Future Human Image. Volume 7, 2017: 113-119. 